\title{
THE INFECTIVITY OF SINGLE FLAGELLATES OF TRYPANOSOMA CRUZI
}

\author{
P.D. Marsden*, S.K.K. Seah and H. Lecherman
}

Single organisms of Trypanosoma cruzi of the virulent Peru strain were isolated by direct visualisation and were injected peritoneally into CFI mice. Single trypanomastigotes of different morphology and from different sources (mouse blood, in vitro culture and bug faeces) were used. Single trypanomastigotes from mouse blood caused parasitaemia and fatality in a high percentage of mice. This was true irrespective of the morphology (broad or narrow form) of the trypanomastigotw. Single organisms of the culture forms were also capable of causing infection, although these were less infectious than single trypanomastigotes obtained from mouse blood or the reduviid bug. The difficulties attendant on the performance of the cloning technique are discussed and some indication is given of how these problems can be overcome.

\section{INTRODUCTION}

Using a Peru strain of Trypanosoma cruzi it has been shown that the number of trypanomastigotes inoculated influences the course of infection in the mouse host as regards survival. Also that one organism of this strain obtained by serial dilution could induce patent, often lethal, infection in a mouse ${ }^{6}$. Since such serial dilution may be attended by ináccuracies ${ }^{4}$ it was decided to directly visualise and inoculate one flagellate in a further series of experiments to study the infective potential of individual flagellates of this strain.

\section{MATERIAL AND METHODS}

The virulent Peru strain of $T . c^{c r u z i} i^{9}$ was continuously maintained in the laboratory by weekly syringe passage in CFI mice, in liquid culture medium (brian heart infusion broth with $10 \%$ human blood) and in Rhodnius prolixus. Suitably diluted suspensions of flagellates from these sources were prepa- red in a diluent of heparinised (5units $/ \mathrm{ml}$ ) normal saline $\mathrm{pH} 6$. Using a fine pipette small drops of suspension ( $1.2 \mathrm{~mm}$ diameter) were dropped onto clean microscope slides and scanned at a magnification of $500 X$. If only one flagellate was seen this was confirmed by a second observer. Epimastigotes and trypanomastigotes can be distinguished in isolates from bug faeces and culture. Trypanomastigotes are characterised by a posterior terminal kinetoplast and a rapid flickering movement across the field. Epimastigotes are broader, without a terminal kinetoplast and less active with clearly defined serpiginous movements of the flagellum. A distinction was made between broad and narrow blood trypanomastigotes. Drops where only one organism was visualised were drawn into a $1 \mathrm{ml}$ plastic syringe already charged with $0.1 \mathrm{ml}$ of normal saline through a fine needle. A different syringe and needle was used for each experiment. The syringe contents were inoculated intra. peritoneally into a 9 to $12 \mathrm{gm}$ male CFI mouse. Only fully motile flagellates were inoculated.

- Department of Clinicat Tropical Medicine; London School of Hygiene and Tropical Medicıne, London Present address: Nucleo Tropical. Faculdade de Ciencias de Saúde; Universidade de Brasília: 70.000 Brasllia, DF, Brasil.

Submitted to publication on April/77 
To assess if infection had occurred the tail blood of mice was examined at 14 and 21 days for the presence of trypanomastigotes. Repeated observations in our laboratory have shown that in almost all animals developing patent parasitaemia infections are detected by examination at this time.

Flagellates from bugs were studied at least 30 days after giving the bugs their infecting blood meal. Flagellates from culture were isolated at least 7 days after innoculating the culture to ensure trypanomastigote differentiation had occurred ${ }^{2}$. To check the accuracy of our cloning technique a series of experiments in which "negative" drops were inoculated into mice were also done in parallel in two series of experiments.

One of us (H.L.) undertook studies of the morphology of flagellate populations derived from the inoculation of a single trypanomastigotes. The number of trypanomastigotes per high power field of a wet monolayer film of tail blood was calculated after examining 100 such fields. At the same time a thick blood smear was stained with Giemsa, examined under $0: 1$ immersion and 100 trypanomastigotes counted and differentiated into broad, intermedlate, and narrow forms. Measurements with an eyepiece micrometer and camera lucida drawings were made of a limited number of organisms (15-20). While lenghts were variable the widths at nuclear level were relatively consistent being from 0.7 to 1.0 micron for slender, 1.1 to 1.6 micron for intermediate and 1.7 to 2.1 vicron for broad trypanomastigotes.

\section{RESULTS}

Table 1 shows the results of 3 sets of experiments using mouse blood trypanomastigotes of the Peru strain isolated from different mouse passages. Only organisms of definite broad or narrow morphology were selected for inoculation. The results show that both morphological forms were more or less equally infectious, assuming that in any injected animal the single organism was placed into the peritoneum. Single organism of the narrow form infected $46 \%$ of the mice with $40.5 \%$ mortality; and single organisms of the broad form caused patent infections in $41.7 \%$ of the mice with similar percentage of mortality.

Table 2 explores the comparative infoctivity to mice of trypanomastigotes derived from two paseage levels. There is no difference in infectivity between isolates of the Peru strain kept in mice for over 100 passages when compared with an isolate that was passed through bugs and only cycled in mice through two passages before doing the experiments.

Table 3 shows that when single trypanomastigotes from different sources are $\infty \mathrm{m}$. pared there does seem to be a difference in their comparative infectivity. Although the results do not reach a statistically analysable level those from culture have the lowest infectivity and those from mouse blood the highest, while those from bug faeces occupy an intermediate position.

Table 4 shows a series of experiments initiated over three days in which the infectivity of drops containing one trypanomastigote were compared with those containing one epimastigote and drops in which no organism was visualised. The source was bug faeces. The result of this experiment suggests that the epimastigotes have a low infectivity.

Table 5 shows a further experiment investigating the infectivity of trypanomastigotes in blood at the 121 passage level. Using the "negative" drop technique to check our results we detected a failure of our cloning technique. One out of $\mathbf{2 0}$ mice injected with drops where no organism was visualised developed parasitaemia.

At this stage in late 1968 after more than 200 individual experiments we decided to abandon further work since we had discovered an error in cur cloning technique. However since the great majority of our infections were probably initiated with single organisms and sources of error are common to all experiments we have decided to publish these comparative results. 
Table 1. Infectivity of single Trypanomastigotes isolated from mouse blood after $\mathbf{4 0}$ or more passages in mice

\begin{tabular}{ccccc}
\hline $\begin{array}{c}\text { Passeges in } \\
\text { mice before } \\
\text { experiment }\end{array}$ & $\begin{array}{c}\text { Morphology } \\
\text { of trypano- } \\
\text { mastipotes }\end{array}$ & $\begin{array}{c}\text { No. of } \\
\text { mice } \\
\text { injected }\end{array}$ & $\begin{array}{c}\text { No. of mice } \\
\text { sowing parat } \\
\text { taemia }(\%)\end{array}$ & $\begin{array}{c}\text { No. with } \\
\text { parasitaemia } \\
\text { dead by } 40 \\
\text { days }(\%)\end{array}$ \\
\hline 40 & Narrow & 16 & $8(50 \%)$ & 8 \\
40 & Broed & 8 & $3(37.5 \%)$ & 3 \\
43 & Narrow & 11 & $2(18.2 \%)$ & 1 \\
43 & Broad & 8 & $3(37.5 \%)$ & 3 \\
50 & Narrow & 10 & $7(70 \%)$ & 6 \\
50 & Brosd & 8 & $4(50 \%)$ & 4 \\
\hline Total & Narrow & 37 & $17(46 \%)$ & $15(40.5 \%)$ \\
& Broad & 24 & $10(41.7 \%)$ & $10(41.7 \%)$ \\
\hline
\end{tabular}

Table 2. Infectivity of single trypanomastigotes isolated from mouse blood after verying passeges in mice

\begin{tabular}{cccc}
\hline $\begin{array}{c}\text { Pasages in mice } \\
\text { before } \\
\text { exposure }\end{array}$ & $\begin{array}{c}\text { No. of mice } \\
\text { injected }\end{array}$ & $\begin{array}{c}\text { No. of mice } \\
\text { with parcet } \\
\text { taemis }(\%)\end{array}$ & $\begin{array}{c}\text { No. with } \\
\text { parasitaemia } \\
\text { deed by } 40 \\
\text { days }(\%)\end{array}$ \\
\hline 107 & 19 & $5(26 \%)$ & $4(21 \%)$ \\
2 & 25 & $6(24 \%)$ & $5(20 \%)$ \\
\hline
\end{tabular}

Table 3. Comparative Infectivity of Single Trypanomastigotes $T$. cruzi from different sources

\begin{tabular}{lccc}
\hline Sources & $\begin{array}{c}\text { No. of } \\
\text { mice } \\
\text { injected }\end{array}$ & $\begin{array}{c}\text { No. of mice } \\
\text { with parasi } \\
\text { taemis (\%) }\end{array}$ & $\begin{array}{c}\text { No. of mice } \\
\text { dead in } \\
\text { one month (\%) }\end{array}$ \\
\hline $\begin{array}{l}\text { Mouse } \\
\text { blood } \\
\begin{array}{l}\text { Reduviid } \\
\text { bug }\end{array}\end{array}$ & 17 & $11(64.6 \%)$ & $8(47.0 \%)$ \\
Culture & 21 & $7(33.0 \%)$ & $7(33.0 \%)$ \\
\hline
\end{tabular}

Table 4. Infectivity of Drops prepared from bug faeces

\begin{tabular}{lccc}
\hline $\begin{array}{l}\text { Content of } \\
\text { drops }\end{array}$ & $\begin{array}{c}\text { No. of mice } \\
\text { injected }\end{array}$ & $\begin{array}{c}\text { No. and \% of } \\
\text { mice with } \\
\text { parasitaemia }\end{array}$ & $\begin{array}{c}\text { No. and \% of } \\
\text { mice deed } \\
\text { in 40 days }\end{array}$ \\
\hline 1 trypanomastigote & 21 & $7(33 \%)^{-}$ & $7(33 \%)$ \\
1 epimastigote & 32 & $4(12.5 \%)$ & $3(9.5 \%)$ \\
No organism & 18 & $0(0 \%)$ & $0(0 \%)$ \\
\hline
\end{tabular}


Table 5. Infectivity of drops prepared from no. 121 passage in mice

\begin{tabular}{lccc}
\hline $\begin{array}{l}\text { Form of } \\
\text { T. cruzi }\end{array}$ & $\begin{array}{l}\text { No. of mice } \\
\text { injected }\end{array}$ & $\begin{array}{l}\text { No. and } \% \\
\text { of mice with } \\
\text { parasitaemia }\end{array}$ & $\begin{array}{l}\text { No. and \% } \\
\text { of mice with } \\
\text { parasitaemia } \\
\text { dead in 40 days }\end{array}$ \\
\hline Trypanomastigotes & 15 & $3(20 \%)$ & $3(20 \%)$ \\
\hline No organism & 20 & $1(5 \%)$ & $1(5 \%)$ \\
\hline
\end{tabular}

Studies of development of parasitaemia in eight mice infected by this technique showed the following results. The prepatent period was about twice as long as in infections induced with $1-2 \times 10^{4}$ organisms, being 12 days as compared with 6 days in infections induced by large numbers of organisms. Clone derived infections tended to be characterised initially by a blood parasitaemia in which slender trypanomastigotes predominated, the broad forms appearing in increasing numbers as the infection progressed. In two mice however, broad forms were in prominence at the begining of the infection and in one mouse after declining the slender form returned in high number just before death 38 days after infection. This pattern was ther efore variable as was the degree of parasitaemia and the outcome of the infection. Of the eight infected mice studied death occurred from 15 to 39 days and one mouse survived.

\section{DISCUSSION}

Although, these experiments were done in 1967-1968 they have only been reported in the literature in abstract for $m^{7}$. Campos and Brener ${ }^{3}$ reported experiments cloning $T$. cruzi into cultures and Miles $^{8}$ achieved success in cloning into culture with two $T$. cruzi strains, one being the Peru strain used in this work. Brief mention of earlier work carried out in this laboratory was made in the paper by Rosenberg et $a /^{10}$. Silva ${ }^{11}$ studied populations of trypanomastigotes derived from clone infections and noted that polymorphism was present in such populations.

The advantage of a technique such as the one we used is to investigate the potential infectivity of individual members of a flagellate population. As pointed out by Lambrecht ${ }^{5}$ such a population may consist of several antigenic and biological variants and one aspect of biological variation could be differences in infectivity. This possibility stimulated this work.

Unfortunately the technique is fraught with difficulties and these are of several types:

1. The drying of the saline drop rendering it less isotonic and killing the organism. For this reason only fully motile flagellates were inoculated. Walker ${ }^{12}$ has reviewed methods of overcoming this difficulty including spotting under viscous silcone which we found unsatisfactory due to the difficulty of drawing up the organism into the syringe. In our experiment we worked as quickly as possible in a high humidity to minimise evaporation.

2. Doubt as to whether the organism was transferred to the mouse peritoneum. It could either fail to be drawn into the syringe or fail to leave it on inoculation. One way to overcome this would be to introduce the drop on a coverslip fragment directly to the abdominal cavity of the mouse through a surgical incision. We did not to this owing to the problem of drying of the drop with the delay.

3. Another source of error which we discovered was the possibility we were not visualising a flagellate in the drop under examination. We believe that when the flagellate is lying within the bright refractile light reflex on the side of the drop it may be invisible. A control using negative drops is therefore an essential for all experiments. Although the combined 38 experiments with negative drops shown in tables 4 and 5 only gave one positive result ( $3 \%$ approximately) this makes us uncerta in of the significance of individual experiments. 
4. Examination of tail blood at 14 and 21 days detects $95 \%$ of mice that show blood parasitaemia in our laboratory with this strain. However, it could be that mice become infected and never show detectable parasitaemia. Numerous observations or serology of such animals by ourselves and in collaboration with other serologists have failed to give reproducible results. To date there is no realiable serology (whether CFT, FAT or (HA) for the mouse model. Recent work in Brazilia (Alvarenga and Marsden, unpusblished) using rechallenge with a lethal dose of Peru trypanomastigotes suggest survivors (that is mice with immunity and therefore surviving such challenge) are less than $5 \%$.

5. The psychological stress and labour of such cloning should be mentioned. We suggest a minimum of three workers is necessary and freqüent changes be made in a weekly schedule to a more varied research activity. It is advisable to work as a team of two in order that both can confirm the microscope field and mouse inoculation can be effected rapidly.

Since these technical difficulties are common to all experiments we had to abandon our original protocol and report here comparative data. It appears that blood strain trypanosomes of both broad and narrow morphology can initiate a fatal infection. Also that in this strain with a long history of mouse and culture passage since 1963, recent passage through the bug does not dramatically alter the number of trypanomastigotes in subsequent mouse passages which have the capacity to induce infection.

Table 3 suggests differences in the capacity of trypanomastigotes derived from bug, culture or mouse sources to infect mice but the numbers are small. It is difficult to isolate trypanomastigotes from culture since the vast majority are epimastigote forms. The lower infective potential of bug derived trypanomastigotes is borne out by another series of experiments where only 4 of 28 single bug trypanomastigotes produced detectable infections in the mice (15\%).

Another aspect worthy of note is that blood trypanomastigotes themselves show wide variation in their infectivity. Comparing the data in tables $1,2,3$ and 5 infectivity rates vary between $20 \%$ and $64.6 \%$. What is responsible for such variations is not clear since conditions were similar in all experiments, but a similar situation has been noted in clones of Trypanosoma brucei ${ }^{12}$.

Table 4 raises a controversial point in that we seem to have demonstrated a low infectivity for epimastigotes which are normally regarded as a non-infectious form. We also have some data on crithidia derived from cultures where in 35 clone experiments of epimastigotes three mice subsequently developed parasitaemia $(9 \%)$. While we would be cautious in interpreting these results as final in view of the technical difficulties already referred to, the possibility of a trypanomastigotes being present and undetected in all positive experiments seems remote. It should be noted that Baker ${ }^{1}$ has suggested in avian trypanosomes that an intermediate pre-trypanosome form may have a low infectivity. Such a form could exist in .T. cruzi and in the unstained state we could not recognise it.

As regards the course of the parasitaemia and longevity of mice infected with single organisms thî́s shows as much variation as those induced with a standard inoculum. As might be expected the prepatent period is prolonged but the duration of parasitaemia, proportion of various morphological forms and mortality times are variable. As in experimental African trypanomiasis the thin narrow forms tend to appear first but some exceptions were noted.

Acknowledgements - We wish to thank Professor A.W. Woodruff for the facilities provided in his department and Mr. L.E. Pettitt for technical assistance.

\section{SUMĀRIO}

Organismos únicos de Trypanosoma cruzi virulento, da cepa Peru, foram isolados por visualização direta e injetados peritonialmente em camundongos CFl. Trypanomastigotas únicos de diferentes morfologia e origem Isangue de camundon- 
gos, cultura in vitro e fezes de triatomíneol foram usados. Trypanomastigotas únicos de sangue de camundongos causaram parasitemia e mortalidade em alta percentagem de camundongos. Isto ocorreu independentemente da morfologia (formas largas e delgadas) dos Trypanomastigotas. Organismos únicos de formas de cultura foram também capazes de causar infecção, embora fossem menos infecciosos que um so trypanomastigota obtido de sangue de camundongo ou de triatomineo. São discutides as dificuldades presentes na execução da técnica de "cloning" e é dada orientação de como estes problemas podem ser superados.

\section{REFERENCES}

1. BAKER, L.R. - Studies on Trypanosoma avium IV. The development of infective metacyclic trypanosomes in cultures grown in vitro. Parasitology. 56: 15. 1966.

2. CAMARGO, E.P. - Growth and diffo rentiation of Trypanosoma cruzi. I. Ori- gin of metacyclic trypanosomes in liquid medium. Rev. Inst. Med. Trop. Såo Paulo. 6.93, 1964.

3. CAMPOS, D. \& BRENER, Z - Tentativa de obtenção de clones de Trypanosoma cruzi. Ciência e Cultura. 20:642, 1967.

4. CANTRELL, W. - Mutation rate and antigenic variation in Trypanosoma equiperdum. J. Infect. Dis. 103.263, 1958.

5. LAMBRECHT, F.L. - Biological variation in trypanosomes and their relation to the epidemiology or Chagas' disease. Rev. Inst. Med. Trop. São Paulo. 7:346, 1965.

6. MARSDEN, P.D. - Trypanosoma cruzi infectious in CFI mice. I. Mortality with different doses of trypanosomes. Ann. Trop. Med. Parasit. 61.57, 1976.

7. MARSDEN, P.D.; SEAH, S.K.K. \& LE-
CHERMAN, H. - The infectivity of single organisms of Trypanosoma cruzi. Proceeding third International Congress of Protozoology. Leningrad, p. 307. 1969.

8. MILES, M.A. - Cloning Trypanosoma cruzi. Trans. Soc. Trop. Med. Hyg. 68.256, 1974.

9. NUSSENZWIEG, V. \& GOBLE, F.C. Further studies on the antigenic constitution of strains of Trypanosoma (Schizotrypanum) cruzi. Exp. Parasit. 18:224, 1966.

10. ROSENBERG, M.E.; MARSDEN, P.D. \& PETTIT, L.E. - The infectivity of cultural source of a Peru strain of Trypanosoma cruzi for CFI mice and reduviid bugs. Ann. Trop. Med. Parasit. 63:207, 1969.

11. SILVA, LH.P. - Observações sobre o ciolo evolutivo do Trypanosoma cruzi. Rev. Inst. Trop. Med. São Paulo. 1.99, 1959.

12. WALKEA, P. $J$ - Reproduction and hereditary in Trypanosomes. A critical review deoling mainly with the African species in the Mammalian host. Inst. Rev. Cytology. 17:51, 1964. 